\title{
ПРОФИЛАКТИЧЕСКАЯ МЕДИЦИНА - ОСНОВА СОХРАНЕНИЯ ЗДОРОВЬЯ НАСЕЛЕНИЯ
}

\author{
Н. В. Полунина, Ю. П. Пивоваров, О. Ю. Милушкина \\ Педиатрический факультет, Российский национальный исследовательский университет имени Н. И. Пирогова, Москва
}

\begin{abstract}
Профилактическая медицина - это комплекс медико-социальных мероприятий, направленных на охрану и укрепление здоровья населения, предупреждение возникновения заболеваний, устранение факторов риска их возникновения. Она включает как медицинские мероприятия, так и создание благоприятных условий труда и быта, отдыха и физического воспитания, организацию здорового и полноценного питания различных групп, оздоровление окружающей среды, повышение благосостояния и улучшение условий жизни населения. В статье представлен обзор научных исследований по оценке воздействия на здоровье населения, в том числе детского, различных факторов внешней среды, предложены конкретные мероприятия по профилактике, опирающиеся на эти исследования, и меры, которые разрабатываются по нивелированию негативных для здоровья факторов и активному внедрению в повседневную жизнь позитивных факторов. Профилактическая модель современного здравоохранения России направлена на предупреждение развития заболеваний детского и взрослого населения, увеличениепродолжительности жизни граждан, формирование установок к здоровому образу жизни и создание безопасных условий окружающей среды.
\end{abstract}

Ключевые слова: просилактика, формирующие здоровье факторы, взрослое население, детское население, здоровый образ жизни

$\bigotimes$ Для корреспонденции: Ольга Юрьевна Милушкина

ул. Островитянова, д. 1, г. Москва, 117997; olmilushkina@mail.ru

Статья получена: 04.09.2018 Статья принята к печати: 05.10.2018

DOI: $10.24075 /$ vrgmu.2018.058

\section{PREVENTIVE MEDICINE IS A CORNERSTONE OF HEALTH PROMOTION}

Polunina NV, Pivovarov YuP, Milushkina OYu凶

Faculty of Pediatrics, Pirogov Russian National Research Medical University, Moscow

Preventive healthcare encompasses a broad range of medical and social interventions aimed at protecting and promoting public health, averting diseases or reducing the risk of their development. Preventive measures seek to create conducive working conditions and good resting environment, promote physical exercise, healthy nutrition, personal hygiene and sanitation, and eventually improve the well-being of the population. This article reviews a number of research works into the impact of various factors on the health of adults and children. Based on their findings, we propose measures for reducing the effects of harmful factors and incorporating positive factors in our daily life. The model of preventive healthcare adopted in Russia is aimed at preventing adult and child morbidity, increasing life expectancy, promoting positive attitude to health, and creating safe environment.

Keywords: prevention, health factors, adults, children, healthy lifestyle

$\triangle$ Correspondence should be addressed: Olga Yu. Milushkina

Ostrovityanova 1, Moscow, 117997; olmilushkina@mail.ru

Received: 04.09.2018 Accepted: 05.10.2018

DOI: $10.24075 /$ brsmu.2018.058

\section{Важность совместных социально-экономических и медико-организационных действий в профилактической медицине}

Важнейшей задачей государства и общества является сохранение и укрепление здоровья населения [1, 2]. Перед отечественным здравоохранением всегда стояла и стоит в настоящее время задача поиска путей, направленных на позитивные сдвиги в состоянии здоровья детей и взрослых. Именно поэтому среди принципов, лежащих в основе организации системы здравоохранения, главным является социально-профилактическое направление, реализация которого позволяет сохранять здоровье [3].

Социально-профилактическое направление здравоохранения - это комплекс социально-экономических и медицинских мероприятий, направленных на укрепление и сохранение здоровья населения. Профилактическое направление здравоохранения не может быть сведено лишь к отдельным медицинским мерам, в том числе к осуществлению гигиенических мероприятий, проведению вакцинации, соблюдению санитарного законодательства и другим. Претворение государством различных аспектов профилактического направления является одним из факторов, влияющих на сознание людей, на внедрение в их повседневную деятельность элементов здорового образа жизни.

В связи с этим реализация просрилактического направления предполагает осуществление в комплексе социально-экономических и медико-организационных действий. Профилактическое направление, таким образом, всесторонне охватывает социальную сферу жизни населения: создание благоприятных условий труда и быта, отдыха и физического воспитания, организацию здорового и полноценного питания различных групп, улучшение условий окружающей среды, повышение благосостояния и улучшение условий жизни населения, что в свою очередь способствует гармоничному развитию физических и духовных сил человека. В таком 
широком аспекте профилактика выходит за пределы медицины и системы здравоохранения, превращается в социально-профилактическое направление деятельности государства.

В число мер входят не только лечебно-профилактические, но и самые разнообразные психологические, биологические и социально-экономические воздействия, которые чаще всего направлены на преодоление факторов риска, характеризующих нездоровый образ жизни, неблагоприятные производственно-бытовые условия.

Разделение профилактических мероприятий на социально-экономические, психолого-социальные, социальногигиенические и медицинские весьма условно, главным является достижение высоких показателей здоровья населения, что возможно только при совместных усилиях заинтересованных сторон и комплексной реализации всех аспектов профилактического направления.

\section{Становление профилактической медицины как науки}

Концепция профилактики начинала формироваться с понимания значимости предупреждения появления болезней, предотвращения их тяжелого течения. Постепенно накапливался опыт и формировался свод санитарных правил по безопасности питьевой воды, пищевых продуктов, естественной и искусственной освещенности, по микроклиматическим параметрам для жилых и общественных зданий, радиационной безопасности, по соблюдению личной гигиены, следованию принципам, предохраняющим от заразных болезней, гигиеническим рекомендациям по режиму дня, регламентации сна и отдыха, приему пищи, проведению закаливающих процедур, физической активности $[4,5]$. Научными исследованиями были установлены взаимосвязь и единство организма и внешней среды, показана роль социальных факторов в сохранении здоровья и предупреждении болезней, что позволило сформулировать основные направления общественной профилактики через оздоровление условий коллективной жизни [6-8].

В марте 1919 г. в нашей стране профилактическое направление, включающее «проведение широких оздоровительных и санитарных мер, имеющих целью предупреждение развития заболеваний», было провозглашено как ведущее направление отечественного здравоохранения. В настоящее время оно не потеряло своего значения. В директивных документах подчеркивается, что реализация профилактики в виде осуществления системы социально-экономических и медицинских мероприятий направлена «на предупреждение и расширение сокращения болезней, ликвидацию массовых инфекционных заболеваний, на дальнейшее увеличение средней продолжительности жизни» [1].

Стратегическим направлением социальной политики государства является разработка различных мероприятий по охране и укреплению здоровья населения, что особенно актуально в настоящее время, когда усиливается экологический кризис, когда в стране имеют место неблагоприятные демографические показатели, когда уровень заболеваемости важнейшими неэпидемическими болезнями среди различных возрастно-половых и социальных групп достаточно высок.

В таком понимании профилактическое направление становится основой социальной политики нашего государства и общества в области здравоохранения, основой стратегии по охране и улучшению здоровья населения.
Под просилактикой (от греч. prophilacticos предохранение, предупреждение) в медицине понимается многосторонняя деятельность государства и системы здравоохранения, включающая выявление причин заболеваний и травм, устранение или нивелирование их негативного воздействия на человека. Различают индивидуальную и общественную профилактику; первичную профилактику, когда эти меры направлены на борьбу с непосредственной причиной заболевания, и вторичную профилактику, когда воздействие оказывают на условия и факторы, способствующие предотвращению причин возникновения осложнений имеющегося заболевания или травмы.

\section{Социально-гигиенические факторы в формировании здоровья населения}

Конкретные мероприятия по просилактике базируются на установлении роли различных факторов в формировании здоровья населения и соответственно разработке способов нивелирования негативных для здоровья факторов и активного внедрения в повседневную жизнь позитивных факторов. С этой целью проводятся социально-гигиенические исследования как за рубежом, так и в нашей стране, в том числе в РНИМУ им. Н. И. Пирогова на кафедре гигиены и кафедре общественного здоровья и здравоохранения, экономики здравоохранения, результаты которых успешно реализуются. Изучение особенностей здоровья и его факторной обусловленности должно проводиться непрерывно и с учетом постоянно меняющихся условий окружающей среды и состояния здоровья населения.

Опубликованные работы дали возможность все факторы, оказывающие влияние на показатели здоровья, систематизировать и распределить на четыре группы:

1) социально-экономические условия и образ жизни;

2) условия внешней среды;

3) биологические факторы;

4) деятельность служб системы здравоохранения.

\section{Образ жизни}

Наибольшее влияние на здоровье человека оказывает образ жизни (более 50\% среди всех факторов). Примерно 20-25\% приходится на загрязнение окружающей среды, 15-20\% на биологические факторы и примерно 10-15\% составляет деятельность органов и учреждений здравоохранения. Приведенные данные подтверждены в исследованиях других авторов [9].

Следует учитывать, что представленное соотношение удельного веса факторов, влияющих на здоровье, относится как к благоприятным показателям, так и к неблагоприятным. По отношению K нездоровью эти факторы выступают в качестве факторов риска, создающих неблагоприятный фон и тем самым способствующих возникновению болезни, а в отношении благоприятных критериев здоровья - в качестве позитивных характеристик, способствующих сохранению и поддержанию здоровья.

Следует помнить, что охрана и укрепление здоровья важны не только для лиц с неудовлетворительными показателями состояния здоровья $[10,11]$, но и для представителей здорового контингента, не имеющих отклонений в состоянии здоровья [12-17], поскольку результат реализации мероприятий по оптимизации здоровья у различных групп населения способствует 
успешному экономическому развитию государства, поддержанию его стабильности и социальной безопасности.

В настоящее время имеется более 40 определений понятия "образ жизни», в том числе здорового и нездорового. Наиболее часто образ жизни характеризуется как собирательное понятие, включающее социально-гигиенические, психологические, медицинские и экономические критерии. В то же время дано краткое, но емкое определение образа жизни как общественного явления, неразрывно связанного со способом производства, которое характеризует «определенный способ деятельности индивидов, определенный вид их жизнедеятельности, их определенный образ жизни» [18].

Иными словами, под образом жизни понимается определенный исторически сложившийся вид активности человека, группы людей, населения в материальной и нематериальной (духовной) ссерах жизни. Изучению образа жизни значительное внимание уделяют представители различных специальностей (психологи, психиатры, философы, юристы, социологи, врачи и др.), все они исследуют мотивацию и характер поведенческих актов человека и группы людей с различных сторон, поскольку деятельность (активность) человека проявляется в самых разнообразных сферах и оказывает непосредственное влияние на его здоровье.

Проведенные исследования позволили определить воздействие социальных условий жизни на состояние здоровья отдельных лиц и групп людей. Результаты этих комплексных социально-гигиенических исследований выявили корреляционную связь между социальногигиеническими факторами и показателями здоровья. Отмечено, что при одних и тех же условиях деятельность человека и состояние его здоровья неоднозначны, поэтому следующая группа подобных исследований была посвящена изучению различных аспектов образа жизни и их роли в формировании здоровья населения. Условно были выделены такие формы деятельности, как трудовая и внетрудовая, которые в свою очередь подразделяются на профессиональную, общественно-политическую, познавательную, культурно-просветительскую, бытовую, воспитательную и иные формы деятельности. Необходимо учитывать, что различные виды активности человека, с одной стороны, характеризуются своими критериями и оценками, а с другой стороны, взаимосвязаны и дополняют друг друга, что позволяет дать всесторонний анализ образа жизни и установить его влияние на состояние здоровья изучаемой группы населения.

\section{Трудовая деятельность}

Неотьемлемой частью жизни человека является трудовая деятельность, которая во многом не только определяет целостную характеристику образа жизни, но и оказывает существенное влияние на различные показатели здоровья. Среди параметров, характеризующих производственнотрудовую активность, наиболее значимы для здоровья продолжительность трудового стажа, характер сложившегося морально-психологического климата, наличие профессиональных вредностей [12, 19-21].

Между трудовым стажем и состоянием здоровья определена прямая достоверная корреляционная зависимость $(r=+0,639 ; m= \pm 0,08)$, а величина трудового стажа коррелирует с возрастом работающих $(r=+0,714$; $m= \pm 0,09)$ и с морально-психологическим климатом $(r=+0,513 ; m= \pm 0,07)$. Выявлено, что среди работающих старшего трудоспособного возраста имеется прямая достоверная корреляционная зависимость уровня хронической заболеваемости от возраста $(r=+0,924$; $m= \pm 0,03 ; p<0,01)$ и с морально-психологическим климатом $(r=+0,708 ; m= \pm 0,04 ; p<0,01)$.

Ухудшение состояния здоровья с увеличением возраста и стажа работы диктует необходимость более детального изучения данных факторов, влияющих на здоровье. Отмечено, что среди лиц, у которых на работе сложился благоприятный морально-психологический климат, длительность стажа работы не оказывает негативного Влияния на здоровье [17, 22, 23].

Известно, что на состояние здоровья человека значимое влияние оказывает работа во вредных условиях. В среднем у 25-35\% женщин и у 57-63\% мужчин трудовая деятельность была связана с наличием профессиональных вредностей различного характера (химических, температурных, гипокинетических, радиационных и т. д.). Особенно неблагоприятно длительное воздействие вредных факторов на организм человека.

В последнее время наиболее часто в разряд профессионально вредных относят работу на компьютере, особенно в течение длительного времени (более 6 ч в день непрерывной работы) [22, 24]. Учитывая тенденцию все более широкого использования компьютерной техники во всех сферах производственной и бытовой деятельности, следует признать, что в настоящее время воздействие компьютера и мобильного телефона на организм является одним из ведущих и пока малоизученных факторов риска. Весьма неблагоприятно воздействие сразу нескольких факторов риска, связанных с производственным процессом. Установлено, что у 37-42 человек из 100 опрошенных имело место сочетание 2-3 неблагоприятных факторов производственной среды, причем среди мужчин это наблюдается достоверно чаще, чем среди женщин.

Важнейшей проблемой в настоящее время является бесконтрольное использование детьми и подростками информационно-коммуникационных устройств. Суммарная продолжительность использования таких устройств школьниками в учебные дни составляет около 7 ч в день, юношами-студентами - около 8,5 ч, а девушкамистудентками - около 10 ч в день. Длительность непрерывного пользования составляет около 1,5-2 ч. Зачастую устройства используются не только в стационарных условиях (на рабочем месте школьника и студента дома, в классе, аудитории), но и в «дороге» (местах, где организована зона wi-fi, в том числе в транспорте). Весьма популярны для этого коридоры, холлы и рекреационные помещения. Именно там на переменах и в перерывах школьники и студенты используют электронные устройства. Среди жалоб, возникающих при этом у школьников и студентов, чаще всего отмечаются головная боль, усталость глаз, боль в области глаз, расплывчатость изображения, ощущение мельканий перед глазами, т. е. жалобы, укладывающиеся в понятие «астенопия». Установлены достоверные различия в количестве жалоб, предъявляемых школьниками и студентами: у студентов возникает достоверно больше жалоб $(p<0,05)$ на боли в области глаз и расплывчатость изображения. Возникновение усталости глаз сопряжено с частотой использования компьютера (коэффициент сопряженности Пирсона 0,7; $p<0,001)$, ноутбука (коэффициент сопряженности Пирсона 0,7; $p<0,001$ ); планшета (коэффициент сопряженности Пирсона 0,6; $p<0,001)$ [25]. 


\section{Внетрудовая активность}

Внетрудовая активность является важнейшей стороной образа жизни и включает в себя отношения людей в браке, организацию своего жилища, отношение к существующему материальному достатку, распределение и выполнение обязанностей между членами семьи, соблюдение семейных традиций, характер проведения досуга и другие аспекты жизнедеятельности в быту.

Анализ жилищных условий с учетом типа квартиры, численности проживающих на данной площади и соответственно плотности заселения квартиры, планировки квартиры, наличия подсобных помещений, степени благоустройства и комфортности имеющегося жилья показал, что ведущим фактором является удовлетворенность населения своими жилищными условиями. Так, среди лиц, проживающих в объективно неудовлетворительных жилищных условиях, 21,3\% жителей вполне удовлетворены ими, а среди проживающих в объективно хороших жилищных условиях 27,1\% жителей не удовлетворены таковыми [13, 26-31]. При этом в первую очередь на здоровье оказывает влияние именно степень удовлетворенности, которая является составной частью психоэмоционального состояния человека $(r=+0,416$; $m= \pm 0,06 ; p<0,01)$.

Результаты исследований свидетельствуют, что только 18-23\% опрошенных удовлетворены своим материальным положением, а 26-32\% населения оценивают его как неудовлетворительное. В целом население трудоспособного возраста в 52-56\% случаев характеризует свое материальное положение как «жизнь от зарплаты до зарплаты». Несмотря на это 70-74\% семей имеют машину, 68-72\% имеют дачный участок, 38-42\% имеют возможность проводить отпуск вне постоянного места жительства. Приведенные данные позволяют сделать вывод, что более половины лиц трудоспособного возраста можно отнести к группе со средним уровнем дохода.

Психоэмоциональное состояние занимает важное место в характеристике образа жизни и во влиянии на здоровье обследуемых. Психоэмоциональное состояние включает характер сложившихся взаимоотношений между членами семьи, наличие или отсутствие внутрисемейных конфрликтов, степень соблюдения определенных традиций. В целом психоэмоциональное состояние оценивается уровнем удовлетворенности сложившегося в семье микроклимата. Следует учитывать, что на психоэмоциональное состояние семей оказывает также степень удовлетворенности материально-бытовыми условиями. Полученные данные показали, что в целом в большинстве обследованных семей имеет место хорошее (28-32\%) и удовлетворительное (49-53\%) психоэмоциональное состояние их членов. В семьях с неудовлетворительным психоэмоциональным состоянием отмечены частые и трудноразрешимые конфликтные ситуации, которые, как правило, были обусловлены неудовлетворительными материально-бытовыми условиями, разногласиями по воспитанию детей и внуков, злоупотреблением спиртными напитками, наличием вредных привычек, тяжелыми переживаниями. Выявлено, что с увеличением возраста удельный вес лиц, отмечающих наличие трудноразрешимых конфликтных ситуаций, заметно сокращается с 21-23\% в возрасте 30-40 лет до 18-19\% в возрасте 40-50 лет и до 16-17\% в возрастной группе 50-60 лет и старше. Обращает на себя внимание, что между состоянием здоровья и психоэмоциональным состоянием установлена прямая корреляционная зависимость $(r=+0,328 ; m= \pm 0,05 ; p<0,01)$.

Использование регрессионного анализа позволило получить данные о взаимосвязи медико-биологических и социальных факторов и морфофрункционального состояния детей и подростков. Получены следующие стандартизированные коэффициенты регрессии: прием лекарств матерью во время беременности $(0,36)$, порядковый номер родов $(-0,27)$, состав семьи $(0,27)$, образование отца $(0,25)$, конфликтная семейная обстановка $(0,24)$ [32].

Учитывая значимую роль психоэмоционального состояния на здоровье человека, были проанализированы причины, оказывающие позитивное влияние на формирование положительного психоэмоционального статуса. Имеющиеся данные свидетельствуют, что подавляющее большинство обследованных среди факторов, способствующих формированию положительного психоэмоционального статуса, выделяют наличие гарантированного рабочего места (80-84\%), материальный достаток (78-80\%), хорошие жилищные условия (70-74\%) и доброжелательные взаимоотношения между членами семьи (64-68\%), отсутствие конфликтов в семье (52-56\%), удовлетворенность отдыхом (44-48\%). Детальное изучение ответов респондентов выявило существенные различия между мужчинами и женщинами в ранговом распределении названных выше причин, оказывающих позитивное влияние на психоэмоциональное состояние. Так, если мужчины на первое место поставили гарантированность работы и доброжелательные взаимоотношения между членами семьи, то женщины - материальный достаток и хорошие жилищные условия. Для более старших респондентов повышается ценность сохранения здоровья членами семьи, наличие в семье доброжелательных взаимоотношений и отсутствие конфликтных ситуаций. В целом респонденты называли 2-3 причины, способствующие положительному психоэмоциональному климату в семье.

\section{Медицинская активность}

Особое место среди характеристик образа жизни занимает медицинская активность, которая оказывает самое непосредственное влияние на здоровье, поэтому при осуществлении профилактической работы среди населения главное внимание должно быть уделено воспитанию позитивных привычек и устранению негативного отношения к этой необходимости. Медицинская активность включает своевременные посещения врача с лечебной и профилактической целями, выполнение рекомендаций медицинского персонала, избавление от вредных привычек, повышение уровня медицинской грамотности, своей и окружающих. Медицинская активность включает в себя такие формы медицинского поведения, как отношение человека к питанию, занятиям физкультурой и спортом, к употреблению алкоголя, курению, к поддержанию в норме массы своего тела, к необходимости обращения к врачу в случае заболевания, проведению просилактического обследования, соблюдению гигиенических норм, режима дня и другие признаки [31, 33-37].

Перечисленные проявления медицинской активности человека зависят во многом от общего уровня культуры, образования, психологической установки, условий жизни, благосостояния, состояния здравоохранения и других факторов. Среди факторов образа жизни, характеризующих медицинскую активность и оказывающих 
самое непосредственное влияние на здоровье, ведущее место принадлежит уровню медицинской грамотности. Прежде всего он проявляется в наличии или отсутствии интереса $\mathrm{k}$ медицинской информации, $\mathrm{K}$ желанию получения знаний о влиянии факторов риска на здоровье, о возможностях и технологиях по его сохранению.

Особое место в повышении уровня медицинской грамотности занимает чтение медицинской литературы, просмотр соответствующих телепередач, посещение лекций и бесед, проводимых медицинскими работниками, поскольку все они дают информацию о здоровье, о факторах риска и методах их нивелирования [20, 27, 28, 38-40].

Полученные данные свидетельствуют, что только 27-38 человек из 100 стремятся получить подобную информацию. Среди пациентов, имеющих хроническую патологию и состоящих под диспансерным наблюдением этот показатель выше (65-70 человек из 100 опрошенных). Обращает на себя внимание тот факт, что повышенный интерес населения к получению медицинских знаний, как правило, связан с состоянием их здоровья. Пациенты с хроническими заболеваниями достоверно в 2 раза чаще читают медицинскую литературу в сравнении с лицами, не имеющими хронического заболевания.

Установлено, что из каждых 100 респондентов, повышающих уровень медицинской грамотности, читают научно-популярную медицинскую литературу 68,1 человек, изучают специальную медицинскую литературу 9,4 человека, смотрят специальные телевизионные программы 41,6 человек, регулярно слушают радиопередачи на медицинские темы 15,2 человека, беседуют с врачом 11,2 человека, а слушают лекции специалистов по наиболее актуальным проблемам медицины лишь 1,6 человек. Полученные данные свидетельствуют о необходимости уделения большего внимания санитарнопросветительской работе, способствующей пробуждению интереса к научно-популярной литературе, видео- и аудиопродукции, телепередачам на медицинские темы, направленным на сохранение здоровья населения.

Медицинская грамотность в значительной мере определяет медицинское поведение. Важнейшим его проявлением является отношение К необходимости посещения врача с лечебной и профилактической целями, к готовности выполнять советы и рекомендации специалиста. Результаты исследования показали, что наиболее частым поводом для обращения к врачу является заболевание, однако в первый день обращается лишь 2432\% заболевших. Кроме заболевания поводом обращения к врачу у каждого второго респондента является оформление различных медицинских документов (листка нетрудоспособности, различных справок, санаторнокурортной карты и т. д.). Обращает на себя внимание, что 24-30\% населения трудоспособного возраста самостоятельно инициируют проверку своего здоровья, но при этом лишь 10-12\% считает необходимым обратиться к врачу за получением совета по его сохранению. Установлено, что даже в тех случаях, когда пациенты имели хроническое заболевание и состояли на диспансерном учете, только 64-68\% из них посещали врача регулярно.

Известно, что полноценный ночной отдых восстанавливает душевные и физические силы организма. Однако результаты исследования свидетельствуют, что лишь 10-18\% взрослого населения имеют достаточную продолжительность ночного сна. Значительная часть респондентов указывает на более низкую продолжительность ночного отдыха: у 34-42\% населения длительность ночного сна составляет менее 6 ч. Помимо длительности ночного сна важной характеристикой ночного отдыха является степень удовлетворенности им. Установлено, что 42-58\% населения удовлетворень своим сном и его продолжительностью, однако среди женщин таковых достоверно в 1,4-1,8 раза выше, чем среди мужчин. Для нормализации сна женщины в сравнении с мужчинами чаще в 2,0-2,5 раза употребляют лекарственные препараты против бессонницы.

Снижается продолжительность ночного сна и у подростков. Отход ко сну у школьников чаще происходит в 22:00-23:00 (45,9\%), реже в 23:00-24:00 (35,6\%), еще реже в 00:00-01:00 (11,5\%). Наиболее часто отход ко сну у студентов происходит в 23:00-24:00 (60,7\%), реже в 00:00-01:00 (34,1\%). Такое позднее время отхода ко сну снижает время ночного сна у школьников до 431,0 \pm 70, мин (в среднем 7 4), у студентов - до 402,7 \pm 89,5 мин (в среднем 6,5 4) [41, 42]

Одним из последствий сложившегося типа поведения человека, его образа жизни (характера питания, отношения к двигательной активности) является степень соответствия имеющегося веса его оптимальному значению, поскольку несоответствие массы тела нормальному значению (как избыток, так и недостаток массы тела) может способствовать возникновению различных заболеваний. Установлено, что за своим весом следят чуть менее половины 42-48\% опрошенных, причем женщины в сравнении с мужчинами делают это достоверно в 1,5-2,0 раза чаще. При анализе причин, вынуждающих следить за весом, выявлено, что основным побудительным моментом, заставляющим контролировать свой вес, у пациентов, имеющих хронические заболевания, является ухудшение состояния здоровья (20-32\%), а в группе лиц, не имеющих хронических заболеваний, стремление сохранить стройную фигуру (22-32\%), причем у молодых достоверно чаще, чем у лиц более старшего возраста. Отмечено, что лишь 25-37\% лиц с избыточным весом стремятся использовать различные методы для его нормализации, что свидетельствует о наличии низкой медицинской активности у значительной части населения. Результаты опроса показали, что среди опрошенных, следующих советам врача, достоверно $(p<0,05)$ больше в 1,5 раза тех, кто следит за своим весом.

Как правило, в качестве меры, способствующей нормализации массы тела, используется изменение образа жизни, в том числе изменение питания и активное внедрение в повседневный быт двигательной активности. Изучение характера питания в одном из экспериментов показало, что 52-58\% взрослого населения нарушают режим питания, в том числе у 34-38\% опрошенных имеет место нерегулярный прием пищи, у 26-34\% он сокращен в течение дня до двух раз, у 23-28\% - прием избыточного количества мучных продуктов, соли, копченостей, сладостей и других продуктов. Сравнительный анализ выявил, что среди лиц с хроническими заболеваниями достоверно $(p<0,05)$ в 1,9-2,4 раза больше лиц с различными нарушениями питания, чем среди опрошенных, не имеющих хронических заболеваний.

В случае недостаточной двигательной активности, как правило, имеет место не только появление избыточной массы тела, но и застойные явления в органах малого таза, что способствует развитию нарушений со сторонь репродуктивных органов, ухудшению других показателей здоровья $(r=-0,418 ; m= \pm 0,0022 ; p<0,0001)$. Полученные 
данные свидетельствуют, что значительная часть населения (74-82\%) ведет малоподвижный образ жизни, причем женщин среди них достоверно $(p<0,05)$ в 1,5-2,0 раза больше, чем мужчин.

К одному из важнейших аспектов образа жизни, характеризующих медицинское поведение населения и оказывающих самое непосредственное влияние на здоровье, относится курение. Установлено, что удельный вес курящих среди остального населения колеблется от 28 до 43\%. Более половины из числа «курильщиков» (54-62\%) выкуривают в сутки до 20 сигарет и имеют стаж курения 5-10 лет, составляя группу со средним уровнем интенсивности курения. Кроме того, рядом с курящими находится 21-37\% населения (пассивное курение). В целом с учетом активного и пассивного курения значительная часть населения были отнесены к группе риска, что влечет ухудшение здоровья, особенно подрастающего поколения. Анкетирование по поведенческим факторам риска среди школьников позволило установить, что в настоящее время среди 15-летних подростков регулярно курят 12,7\% девушек и 15,1\% юношей, пробовали курить 54,6\% девушек и 48,1\% юношей. Наиболее распространенный возраст начала курения среди юношей - 14 лет, среди девушек - 13 лет, самый ранний возраст составил 6 и 8 лет соответственно. Об употреблении алкоголя 1 раз в месяц и реже указали 32,0\% юношей и 29,1\% девушек, совсем не употребляют алкоголь 64,1\% опрошенных юношей и $58,1 \%$ девушек. Анализ распространенности вредных привычек среди подростков и молодежи показывает, что образ жизни мальчиков и девочек практически не различается и девочки подвержены влиянию негативных поведенческих факторов наравне с мальчиками. Получены статистически значимые связи между снижением силы кистей рук и частотой курения $(r=-0,74 ; p<0,05)$, возрастом, в котором начато курение $(r=-0,33$; $p<0,05)$, временем, проводимым за компьютером $(r=-0,39$; $p<0,05)$ и занятиями спортом $(r=0,34 ; p<0,05)$ [43].

Анализ результатов исследований, проведенных на кафедре общественного здоровья и здравоохранения РНИМУ им. Н. И. Пирогова, позволил дать комплексную оценку медицинской активности населения. В зависимости от полученной суммы баллов обследованные были распределены на три группы по уровню выраженности изученных критериев. Большинство обследованных лиц трудоспособного возраста (53-57\%) относятся к группе со средним уровнем выраженности изученных показателей, каждый четвертый-пятый обследованный (22-26\%) вошел в группу с преимущественно неблагоприятными значениями перечисленных выше факторов, лишь каждый пятый (18-22\%) респондент имел благоприятные показатели не менее чем по 70\% изученных факторов.

Учитывая значимость медицинской активности на состояние показателей здоровья населения, при разработке оздоровительных программ необходимо акцентировать внимание на формирование у населения более активной медицинской позиции. Тем более, что среди указанных критериев преобладают такие, выполнение которых зависит только от желания и убежденности самих пациентов в необходимости сохранения своего здоровья. В связи с этим программа медико-социальной реабилитации должна включать в первую очередь меры воздействия на управляемые факторы образа жизни, а при ее реализации следует обучать пациентов активизированию позитивных и нивелированию негативных составляющих своей медицинской активности.

Важны сочетание убежденности лиц, принимающих решения по изменению внимания к своему здоровью и здоровью окружающих, и активной роли государства и системы здравоохранения в ориентации населения на укрепление своего здоровья, а также достаточное ресурсное обеспечение для осуществления различных оздоровительных мероприятий [33]. Повышение медицинской грамотности - залог успешной работы с пациентами по изменению их образа жизни. Оно позволит устранить в поведении человека вредные привычки и обратить большее внимание на благоприятные для здоровья особенности образа жизни. Формирование стремления к здоровому образу жизни должно стать базой профилактических программ, стержнем стратегии по охране и укреплению здоровья [44-46].

Полученные результаты свидетельствуют о достоверном повышении медицинской активности среди населения и уровня медицинской грамотности (коэффрициент корреляции между указанными признаками: $r=-0,523$; $m= \pm 0,0024 ; p<0,0001)$

\section{ЗАКЛЮЧЕНИЕ}

Рычагом для просрилактики является воспитание гигиенических навыков и санитарное просвещение, осуществление которого возлагается на медицинских работников различного уровня. Сюда можно включить беседы у постели пациентов в лечебно-профилактических учреждениях и в семьях, тематические лекции, наглядные средства массовой информации, демонстрации специально подготовленных фильмов, организацию тематических радио- и телепередач. В основу воспитания гигиенических навыков заложено конкретное воплощение различных гигиенических, профилактических программ. Отечественное здравоохранение обладает достаточными ресурсами для выполнения задач профилактической медицины [47-50].

Залогом сохранения жизни и здоровья граждан России является профилактическая модель современного здравоохранения, направленная на предупреждение развития заболеваний в период от младенчества до пожилого и старческого возраста, увеличение продолжительности жизни населения, формирование установок к здоровому образу жизни и создание безопасных условий окружающей среды, воспитания и обучения, профессиональной деятельности.

\section{Литература}

1. О национальных целях и стратегических задачах развития Российской Федерации на период до 2024 года Указ Президента РФ № 204 от 7 мая 2018 года. Доступно по ссылке: http://www.garant.ru/products/ipo/prime/doc/71837200/

2. О национальном проекте «Здравоохранение». Брифинг Вероники Скворцовой по завершении заседания

президиума Совета при Президенте Российской Федерации по стратегическому развитию и приоритетным проектам. Доступно по ссылке: http://government.ru/dep_news/33207/

3. Лисицын Ю. П., Полунина Н. В. Общественное здоровье и здравоохранение: учебник. М.: Медицина, 2002; 416 с.

4. Онищенко Г. Г. Актуальные задачи гигиенической науки 
и практики в сохранении здоровья населения. Гигиена и санитария. 2015; (3): 5-9.

5. Чучалин А. Г., Онищенко Г. Г., Колосов В. П., Курганова О. П., Тезиков Н. Л., Манаков М. П. и др. Респираторные инфекции у детей: результаты реализации региональной программь вакцинопрофилактики. Педиатрия. Журнал им. Г. Н. Сперанского. 2016; (4): 197-202.

6. Андреева Е. Е., Онищенко Г. Г., Клейн С. В. Гигиеническая оценка приоритетных факторов риска среды обитания и состояния здоровья населения г. Москвы. Анализ риска здоровью. 2016; (3): 23-34.

7. Ракитский В. Н. Проблемы современной гигиены. Гигиена и санитария. 2015; 94 (4): 4-7.

8. Онищенко Г. Г., Ракитский В. Н., Синода В. А., Трухина Г. М., Луценко Л. А., Сухова А. В. Сохранение здоровья работников при внедрении здоровье- и ресурсосберегающей технологии Здравоохранение Российской Федерации. 2015; 59 (6): 4-8.

9. Лисицын Ю. П., редактор. Руководство по социальной гигиене и организации здравоохранения в 2 томах. М.: Медицина, 1987; (1); 149 с.

10. Чемезов А. С. Медико-социальное исследование репродуктивного здоровья беременных женщин и мероприятия по его улучшению [диссертация]. М., 2013.

11. Авсаджанишвили В. Н., Полунина Н. В., Полунина В.В.Роль медицинской активности в формировании здоровья детей, страдающих болезнями органов дыхания. Вестник РГМУ. 2013; (2): 70-5.

12. Карповский А. Г. Состояние здоровья, образ жизни и медико-социальная реабилитация населения старшего трудоспособного возраста [диссертация]. М., 2006.

13. Полунина Н. В., Пшибиева С. В, Аль-Гарахи Т. А., Полунина В. В. Некоторые аспекты сохранения здоровья лиц медикосоциального риска с позиции гуманизма. Общественное здоровье и просилактика заболеваний. 2007; (1): 54-9.

14. Полунина Н. В., Гончарова А. В., Костин А. П., Копецкий И. С. Медико-организационные аспекты реабилитации больных с воспалительными заболеваниями и повреждениями челюстно-лицевой области в амбулаторных условиях Российский медицинский журнал. 2010; (5): 4-8.

15. Юмукян А. В. Особенности состояния здоровья и образа жизни юношей-подростков на современном этапе развития общества. Вестник РГМУ. 2012; (1): 75-9.

16. Полунина Н. В., Курцер М. А., Кутакова Ю. Ю., Чемезов А. С., Черепнина А. Л. Эффективность реализации мероприятий по совершенствованию медицинской помощи женщинам с неблагоприятным течением беременности. Вестник РГМУ. 2012; (6): 76-80.

17. Дубович Е. Г., Полунина Н. В., Кешишян Е. С., Сахарова Е. С. Роль психологического состояния родителей в эффективности медико-социальной реабилитации недоношенного ребенка с тяжелыми формами ретинопатии Российский вестник перинаталогии и педиатрии. 2012; 57 (1): 104-8.

18. Маркс К., Энгельс Ф. Сочинения. 1974; 3: 19.

19. Тимерзянов М. И., Полунина Н. В., Милушкина О. Ю., Пивоваров Ю. П., Полунин В. С., Аль Сабунчи А. А. и др. Гигиеническая оценка условий труда в учреждениях исправительной системы: проблемы и пути решения. Вестник РГМУ. 2017; (6): 42-6.

20. Агаджанян Н. А., Радыш И. В. Качество и образ жизни студенческой молодежи. Экология человека. 2009; (5): 3-8.

21. Жабоева С. Л. Организационно-методические основы моделирования персонисицированных программ просилактики возраст-ассоциированных заболеваний и оценка их эффективности [диссертация]. М., 2017.

22. Доронкин М. В. Комплексное социально-гигиеническое исследование состояния здоровья и организации медицинской помощи сотрудникам органов внутренних дел [диссертация]. М., 2007.

23. Авдеев М. В. Научное обоснование модели профилактической деятельности центров здоровья [диссертация]. СПб., 2015.

24. Дубович Е. Г. Научное обоснование организации медикосоциальной реабилитации детей раннего возраста, родившихся недоношенными [диссертация]. М., 2013.

25. Скоблина Н. А., Милушкина О. Ю., ТатаринчикА. А., Федотов Д. М. Гигиенические проблемы использования информационнокоммуникационных технологий школьниками и студентами. Здоровье населения и среда обитания. 2017; 294 (9): 52-5.

26. Соломатин Д. В. Медико-социальная реабилитация женщин с нарушениями репродуктивного здоровья (комплексное социально-гигиеническое исследование) [диссертация]. М., 2007.

27. Максимова Т. М., Лушкина Н. П. Состояние здоровья и проблемы медицинского обеспечения пожилого населения. М.: ПЕР СЭ, 2012; 224 c.

28. Зиатдинов А. И. Медико-социальные аспекты профилактики заболеваний среди часто болеющих студентов медицинского университета [диссертация]. Казань, 2007.

29. Кабочкин А. А. Медико-социальное исследование здоровья беременных, рожениц и родильниц в крупном промышленном центре [диссертация]. М., 2015.

30. Неволин Ю. С. Научное обоснование организации работы межтерриториального центра здоровья для детей [диссертация]. М., 2016.

31. Зелионко А. В. Обоснование организационно-профилактических мероприятий по совершенствованию системы формирования здоровьесберегающего поведения и улучшения качества жизни населения [диссертация]. СПб., 2007.

32. Милушкина О. Ю. Закономерности формирования морфофункциональных показателей детей и подростков в современных санитарно-гигиеническихи медико-социальных условиях [диссертация]. М., 2013.

33. Максимова Т. М. Современное состояние, тенденции и перспективные оценки здоровья населения. М.: ПЕР СЭ, 2002; 186 c.

34. Майорова Е. К. Современные особенности заболеваемости детей мегаполиса и пути ее снижения [диссертация]. СПб., 2014.

35. Агафонов А. И. Гигиенические основы укрепления здоровья детей и подростков методами физического воспитания [диссертация]. Оренбург, 2015.

36. Нагаев Р. Я. Медико-социальные аспекты охраны здоровья подростков 10-17 лет на уровне субъекта Российской Федерации [диссертация]. М., 2016.

37. Найденова Н. Е. Совершенствование организационных технологий профилактической помощи работающему населению в центре здоровья [диссертация]. М., 2016.

38. Бережной В. Г. Социально-гигиенические аспекты состояния здоровья и условий жизни сельских жителей и обоснование мероприятий по их оздоровлению [диссертация]. М., 2016.

39. Тюмина О. В., Мельников В. А. Здоровье женщин позднего репродуктиного возраста с бесплодием. М.: Академия естествознания, 2016; 210 с.

40. Сухарев А. Г., Игнатова Л. Ф., Стан В. В., Шелонина О. А., Цыренова Н. М., Лукашова Ю. А. Медико-социальная оценка образа жизни школьников. Российский педиатрический журнал. 2014; (3): 37-40.

41. Скоблина Н. А., Милушкина О. Ю., Татаринчик А. А., Федотов Д. М. Место гаджетов в образе жизни современных школьников и студентов. Здоровье населения и среда обитания. 2017; 292 (7): 41-3.

42. Пивоваров Ю. П. Дагаева З. А., Шеина Н. И. Изучение образа жизни учащихся медико-биологических классов города Москвы. Здоровье населения и среда обитания. 2015; 264 (3): $13-15$.

43. Милушкина О. Ю. Физическое развитие и образ жизни современных школьников. Вестник РГМУ. 2013; (3): 68-71.

44. Кононова И. В. Научное обоснование совершенствования организации медицинской и социальной помощи населению старше трудоспособного возраста в субъекте Российской Федерации [диссертация]. Оренбург, 2016.

45. Осыкина А. С. Социально-гигиеническая оценка состояния здоровья и качества жизни студенток медицинского ВУЗа Удмуртской республики [диссертация]. М., 2016.

46. Обкин В. С., Скобельцина К. Н., Иванова А. И. Влияние социальных факторов на семейный досуг дошкольника. 
Социологические исследования. 2013; 350 (6): 62-70.

47. Кучма В. Р., Сухарев А. Г. Гигиена детей и подростков как раздел профилактической медицины. Гигиена и санитария. 2015; 94 (6): 66-70.

48. Стародубов В. И., Сон И. М., Сененко А. Ш., Короткова А. В., Леонов С. А., Цешковский М. С. и др. Общественное здравоохранение и формирование единого профилактического пространства. Менеджер здравоохранения. 2016; (4): 6-13.

49. Хабриев Р. У., Киргизова Н. С. Новый критерий оценки общественного здоровья. Бюллетень Национального научноисследовательского института общественного здоровья им. Н. А. Семашко. 2017; (1): 303-7.

50. Бойцов С. А., Самородская И. В., Семенов В. Ю. Влияние медицинских и немедицинских факторов на смертность населения: экономические факторы. Проблемы социальной гигиены, здравоохранения и истории медицины. 2016; 24 (6): 335-9.

\section{References}

1. O nacional'nyh celjah i strategicheskih zadachah razvitija Rossiijskoj Federacii na period do 2024 goda Ukaz Prezidenta RF \#204 ot 7 maja 2018 goda. Dostupno po ssylke: http://www. garant.ru/products/ipo/prime/doc/71837200/

2. O nacional'nom proekte "Zdravoohranenie». Brifing Veroniki Skvorcovoj po zavershenii zasedanija prezidiuma Soveta pr Prezidente Rossijskoj Federacii po strategicheskomu razvitiju prioritetnym proektam. Dostupno po ssylke: http://government. ru/dep_news/33207/

3. Lisicyn JuP, Polunina NV. Obshhestvennoe zdorov'e zdravoohranenie: uchebnik. M.: Medicina, 2002; 416 s.

4. Onishhenko GG. Aktual'nye zadachi gigienicheskoj nauki i praktiki v sohranenii zdorov'ja naselenija. Gigiena i sanitarija. 2015; (3): 5-9

5. Chuchalin AG, Onishhenko GG, Kolosov VP, Kurganova OP, Tezikov NL, Manakov MP. i dr. Respiratornye infekcii u detej: rezul'taty realizacii regional'noj programmy vakcinoprofilaktiki. Pediatrija. Zhurnal im. GN Speranskogo. 2016; (4): 197-202.

6. Andreeva EE, Onishhenko GG, Klejn SV. Gigienicheskaja ocenka prioritetnyh faktorov riska sredy obitanija i sostojanija zdorov'ja naselenija g. Moskvy. Analiz riska zdorov'ju. 2016; (3): 23-34.

7. Rakitskij VN. Problemy sovremennoj gigieny. Gigiena i sanitarija. 2015; 94 (4): 4-7.

8. Onishhenko GG, Rakitskij VN, Sinoda VA, Truhina GM, Lucenko LA Suhova AV. Sohranenie zdorov'ja rabotnikov pri vnedrenil zdorov'e- i resursosberegajushhej tehnologii. Zdravoohranenie Rossijskoj Federacii. 2015; 59 (6): 4-8

9. Lisicyn JuP, redaktor. Rukovodstvo po social'noj gigiene organizacii zdravoohranenija $\vee 2$ tomah. M.: Medicina, 1987 (1); $149 \mathrm{~s}$.

10. Chemezov AS. Mediko-social'noe issledovanie reproduktivnogo zdorov'ja beremennyh zhenshhin i meroprijatija po ego uluchsheniju [dissertacija]. M., 2013.

11. Avsadzhanishvili VN, Polunina NV, Polunina W. Rol' medicinskoj aktivnosti v formirovanii zdorov'ja detej, stradajushhih boleznjami organov dyhanija. Vestnik RGMU. 2013; (2): 70-5.

12. Karpovskij AG. Sostojanie zdorov'ja, obraz zhizni i medikosocial'naja reabilitacija naselenija starshego trudosposobnogo vozrasta [dissertacija]. M., 2006.

13. Polunina NV, Pshibieva SV, Al-Garahi TA, Polunina W. Nekotorye aspekty sohranenija zdorov'ja lic mediko-social'nogo riska s pozicii gumanizma. Obshhestvennoe zdorov'e i profilaktika zabolevanij. 2007; (1): 54-9.

14. Polunina NV, Goncharova AV, Kostin AP, Kopeckij IS. Medikoorganizacionnye aspekty reabilitacii bol'nyh $s$ vospalitel'nym zabolevanijami i povrezhdenijami cheljustno-licevoj oblasti v ambulatornyh uslovijah. Rossijskij medicinskij zhurnal. 2010; (5): 4-8

15. Jumukjan AV. Osobennosti sostojanija zdorov'ja i obraza zhizni junoshej-podrostkov na sovremennom jetape razvitija obshhestva. Vestnik RGMU. 2012; (1): 75-9.

16. Polunina NV, Kurcer MA, Kutakova JuJu, Chemezov AS, Cherepnina AL. Jeffektivnost' realizacii meroprijatij po sovershenstvovaniju medicinskoj pomoshhi zhenshhinam s neblagoprijatnym techeniem beremennosti. Vestnik RGMU. 2012; (6): $76-80$.

17. Dubovich EG, Polunina NV, Keshishjan ES, Saharova ES. Rol' psihologicheskogo sostojanija roditelej $v$ jeffektivnosti medikosocial'noj reabilitacii nedonoshennogo rebenka $s$ tjazhelymi formami retinopatii. Rossijskij vestnik perinatalogii i pediatrii. 2012; 57 (1): 104-8.

18. Marks K, Jengel's F. Sochineniya. 1974; 3: 19.

19. Timerzjanov MI, Polunina NV, Milushkina OJu, Pivovarov JuP, Polunin VS, Al Sabunchi AA i dr. Gigienicheskaja ocenka uslovij truda $\vee$ uchrezhdenijah ispravitel'noj sistemy: problemy i put reshenija. Vestnik RGMU. 2017; (6): 42-6.

20. Agadzhanjan NA, Radysh IV. Kachestvo i obraz zhizn studencheskoj molodezhi. Jekologija cheloveka. 2009; (5): 3-8.

21. Zhaboeva SL. Organizacionno-metodicheskie osnovy modelirovanija personificirovannyh programm profilaktiki vozrastassociirovannyh zabolevanij i ocenka in jeffektivnosti [dissertacija]. M., 2017.

22. Doronkin MV. Kompleksnoe social'no-gigienicheskoe issledovanie sostojanija zdorov'ja i organizacii medicinskoj pomoshhi sotrudnikam organov vnutrennih del [dissertacija]. M., 2007.

23. Avdeev MV. Nauchnoe obosnovanie modeli profilakticheskoj dejatel'nosti centrov zdorov'ja [dissertacija]. SPb., 2015.

24. Dubovich EG. Nauchnoe obosnovanie organizacii medikosocial'noj reabilitacii detej rannego vozrasta, rodivshihsja nedonoshennymi [dissertacija]. M., 2013.

25. Skoblina NA, Milushkina OJu, Tatarinchik AA, Fedotov DM Gigienicheskie problemy ispol'zovanija informacionnokommunikacionnyh tehnologij shkol'nikami i studentami. Zdorov'e naselenija i sreda obitanija. 2017; 294 (9): 52-5.

26. Solomatin DV. Mediko-social'naja reabilitacija zhenshhin s narushenijami reproduktivnogo zdorov'ja (kompleksnoe social'nogigienicheskoe issledovanie) [dissertacija]. M., 2007.

27. Maksimova TM, Lushkina NP. Sostojanie zdorov'ja i problemy medicinskogo obespechenija pozhilogo naselenija. M.: PER SJe, 2012; 224 s.

28. Ziatdinov Al. Mediko-social'nye aspekty profilaktiki zabolevanij sredi chasto bolejushhih studentov medicinskogo universiteta [dissertacija]. Kazan', 2007.

29. Kabochkin AA. Mediko-social'noe issledovanie zdorov'ja beremennyh, rozhenic i rodil'nic $v$ krupnom promyshlennom centre [dissertacija]. M., 2015.

30. Nevolin JuS. Nauchnoe obosnovanie organizacii raboty mezhterritorial'nogo centra zdorov'ja dlja detej [dissertacija]. M., 2016.

31. Zelionko AV. Obosnovanie organizacionno-profilakticheskih meroprijatij po sovershenstvovaniju sistemy formirovanija zdorov'esberegajushhego povedenija i uluchshenija kachestva zhizni naselenija [dissertacija]. SPb., 2007.

32. Milushkina OJu. Zakonomernosti formirovanija morfofunkcional'nyh pokazatelej detej i podrostkov $\mathrm{v}$ sovremennyh sanitarnogigienicheskih i mediko-social'nyh uslovijah [dissertacija]. M.: 2013.

33. Maksimova TM. Sovremennoe sostojanie, tendencii i perspektivnye ocenki zdorov'ja naselenija. M.: PER SJe, 2002; 186 C.

34. Majorova EK. Sovremennye osobennosti zabolevaemosti detej megapolisa i puti ee snizhenija [dissertacija]. SPb., 2014

35. Agafonov Al. Gigienicheskie osnovy ukreplenija zdorov'ja detej i podrostkov metodami fizicheskogo vospitanija [dissertacija]. Orenburg, 2015.

36. Nagaev RJa. Mediko-social'nye aspekty ohrany zdorov'ja podrostkov 10-17 let na urovne sub"ekta Rossijskoj Federacil [dissertacija]. M., 2016. 
37. Najdenova NE. Sovershenstvovanie organizacionnyh tehnologi profilakticheskoj pomoshhi rabotajushhemu naseleniju v centre zdorov'ja [dissertacija]. M., 2016.

38. Berezhnoj VG. Social'no-gigienicheskie aspekty sostojanija zdorov'ja i uslovij zhizni sel'skih zhitelej i obosnovanie meroprijatij po ih ozdorovleniju [dissertacija]. M., 2016.

39. Tjumina OV, Mel'nikov VA. Zdorov'e zhenshhin pozdnego reproduktinogo vozrasta $s$ besplodiem. M.: Akademija estestvoznanija, 2016; 210 s.

40. Suharev AG, Ignatova LF, Stan W, Shelonina OA, Cyrenova NM, Lukashova JuA. Mediko-social'naja ocenka obraza zhizni shkol'nikov. Rossijskij pediatricheskij zhurnal. 2014; (3): 37-40.

41. Skoblina NA, Milushkina OJu, Tatarinchik AA, Fedotov DM. Mesto gadzhetov v obraze zhizni sovremennyh shkol'nikov i studentov. Zdorov'e naselenija i sreda obitanija. 2017; 292 (7): 41-3.

42. Pivovarov JuP, Dagaeva ZA, Sheina NI. Izuchenie obraza zhizni uchashhihsja mediko-biologicheskih klassov goroda Moskvy. Zdorov'e naselenija i sreda obitanija. 2015; 264 (3): 13-15.

43. Milushkina OJu. Fizicheskoe razvitie i obraz zhizni sovremennyh shkol'nikov. Vestnik RGMU. 2013; (3): 68-71.

44. Kononova IV. Nauchnoe obosnovanie sovershenstvovanija organizacii medicinskoj i social'noj pomoshhi naseleniju starshe trudosposobnogo vozrasta v sub"ekte Rossijskoj Federacii [dissertacija]. Orenburg, 2016.

45. Osykina AS. Social'no-gigienicheskaja ocenka sostojanija zdorov'ja i kachestva zhizni studentok medicinskogo VUZa Udmurtskoj respubliki [dissertacija]. M., 2016.

46. Obkin VS, Skobelcina KN, Ivanova Al. Vlijanie social'nyh faktorov na semejnyj dosug doshkol'nika. Sociologicheskie issledovanija. 2013; 350 (6): 62-70.

47. Kuchma VR, Suharev AG. Gigiena detej i podrostkov kak razdel profilakticheskoj mediciny. Gigiena i sanitarija. 2015; 94 (6): 66-70.

48. Starodubov VI, Son IM, Senenko ASh, Korotkova AV, Leonov SA, Ceshkovskij MS i dr. Obshhestvennoe zdravoohranenie i formirovanie edinogo profilakticheskogo prostranstva. Menedzher zdravoohranenija. 2016; (4): 6-13.

49. Habriev RU, Kirgizova NS. Novyj kriterij ocenki obshhestvennogo zdorov'ja. Bjulleten' Nacional'nogo nauchno-issledovatel'skogo instituta obshhestvennogo zdorov'ja im. NA Semashko. 2017; (1): 303-7.

50. Bojcov SA, Samorodskaja IV, Semenov VJu. Vlijanie medicinskih i nemedicinskih faktorov na smertnost' naselenija: jekonomicheskie faktory. Problemy social'noj gigieny, zdravoohranenija i istorii mediciny. 2016; 24 (6): 335-9. 